\title{
Introduction to the Series
}

The seven books comprising the Macmillan 'Handbooks in Industrial Management' series were from the outset planned as an entity, and together they cover comprehensively yet concisely the varied aspects of knowledge required by those who manage a modern factory or plant. At the same time, care has been taken to ensure that each volume shall be complete in itself, and carry sufficient basic management theory for a proper understanding of its specific subject.

By this means, it has been possible to avoid a common pitfall in the path of many writers on management subjects, namely an attempt to cover all possible ground in one major volume, with varying degrees of success.

By contrast, each author in this series is experienced in the subject of his contribution. A similar pattern has been followed in each book, but each bears the stamp of the personality of its author. Wellestablished principles and tested techniques are explained, but equally new and up-to-date concepts are explored.

It is expected that many practising works managers and mature students will wish to have the whole set on their shelves, but that others will welcome the opportunity of buying single volumes to meet their particular needs.

Thanks are due to the authors for the enthusiasm with which they have joined in the enterprise, and to members of the staff of the Institution of Works Managers for practical support on many occasions.

J. EKINS 
MACMILLAN HANDBOOKS IN INDUSTRIAL MANAGEMENT

Series Editor: J. EkIns, Cranfield Institute of Technology Executive Editor: A. R. PIR IE, Institution of Works Managers

FINANCIAL CONTROL IN MANUFACTURING

C. N. Aydon

INDUSTRIAL LAW AND ITS APPLICATION IN THE FACTORY

Roderick L. Denyer

WORKS ORGANISATION

Alan Lawlor

EMPLOYEE RELATIONS WITHIN THE FACTORY

W. Mitchell with Alan R. Corbett

THE CONTROL OF QUALITY

V. G. Parry

PLANT LAYOUT AND MATERIALS HANDLING

A. W. Pemberton

TECHNIQUES FOR PRODUCTION EFFICIENCY

Ken Swann 


\section{Techniques for Production Efficiency}

\section{KEN SWANN}

M.Sc., C.Eng., M.I.Mech.E., M.I.Prod.E., M.I.W.M.

Head of Management Studies Department

The Polytechnic, Huddersfield

Macmillan Handbooks in Industrial Management published in association with Macmillan Education 
ISBN 978-0-333-14544-9 ISBN 978-1-349-01790-4 (eBook)

DOI 10.1007/978-1-349-01790-4

(C) Ken Swann 1973

Reprint of the original edition 1973

All rights reserved. No part of this publication may be reproduced or transmitted, in any form or by any means, without permission.

First published 1973 by THE MACMILLAN PRESS LTD

London and Basingstoke Associated companies in New York Dublin Melbourne Johannesburg and Madras

SBN 333145445

The paperback edition of this book is sold subject to the condition that it shall not, by way of trade or otherwise, be lent, re-sold, hired out, or otherwise circulated without the publisher's prior consent in any form of binding or cover other than that in which it is published and without a similar condition, including this condition, being imposed on the subsequent purchaser. 


\section{Contents}

Introduction to the Series 1

Foreword by Richard Marsh

Acknowledgements $\quad 8$

1. Introduction 9

2. Variety Reduction 12

3. Value Analysis 22

4. Classification Systems 29

5. Group Technology 38

6. Work Study 46

A. Method Study $\quad 52$

B. Work Measurement 69

7. Production Planning and Control 103

A. Forecasting 107

B. Operations Planning 119

C. Network Analysis 122

D. Inventory Control 142

E. Line of Balance 153

F. Machine Interference 159

G. Line Balancing 163

8. Resource Allocation 172

Name Index $\quad 189$

$\begin{array}{ll}\text { Subject Index } & 191\end{array}$ 


\section{Foreword}

In the world of modern industry, it becomes increasingly necessary for managers to be aware not only of the fundamental principles of good management, but also of the latest techniques necessary for putting those principles into practice.

Works managers in particular, because of the salient position which they hold in the management structure of modern industry and their responsibility for translating policy into execution, must be both educated in sound theory and trained in modern methods.

This series of eight books has been designed to provide the basis of that education and to supplement essential experience.

I welcome the opportunity the Institution of Works Managers has been given to sponsor this venture and commend the books to all present and future managers in industry.

RICHARD MARSH

Chairman, British Rail

President, Institution of Works Managers 


\section{Acknowledgements}

Several authors, publishers and industrial concerns have given permission to reproduce certain figures and tables included in the text and I would record my sincere thanks to C. C. Gallagher for Figs. 4.1, 4.2, 4.3; Holt, Rinehart \& Winston for permission to reproduce Figs. 4.4, 4.5 and Table 4.1, from Techniques of Production Management by Ray Wild; Heinemann for Figs. 5.2 and 5.3 from Production Planning by J. L. Burbidge; the M.T.M. Association for reproduction of their standard tables, and the Journal of Industrial Engineering for Figs. 6в.3 and 6в.4.

My thanks are also due to the many students whose comments and discussions have assisted in the development of the arguments and presentation used, and similarly to my colleagues who have made many useful comments. Finally my thanks to my typists who prepared the manuscript.

K. SWANN 